\title{
Holocene earthquakes on the Zemuhe Fault in Southwestern China
}

\author{
Honglin He $\left({ }^{1}\right)\left({ }^{2}\right)$ and Jinwei Ren $\left({ }^{2}\right)$ \\ $\left(^{1}\right)$ Active Fault Research Center, National Institute of Industrial Science and Technology, Ibaraki, Japan \\ ${ }^{2}{ }^{2}$ Institute of Geology, China Seismological Bureau, Beijing, China
}

\begin{abstract}
The Zemuhe Fault is a prominent active fault in Southwestern China. Seven ravines along a $5 \mathrm{~km}$ long fault scarp indicate seven large magnitude earthquakes in the Holocene. The youngest four ravines were abandoned during four large magnitude earthquakes, the age of which are constrained by radiocarbon data: ravines 7,6 , and 4 formed in association with the earthquakes at A.D. 1850 and A.D. 814, B.C. $4477 \pm 240$ or older, and ravine 5 to a paleo-event between B.C. $4477 \pm 240$ and A.D. 814 . Three trenches excavated by earlier workers together with a trench excavated and analyzed here revealed 3 or 4 earthquakes, which are consistent with those indicated by the youngest five ravines. These radiocarbon-dated earthquakes mainly occurred within two temporal clusters: the older cluster of two paleoearthquakes occurred approximately between B.C. 4250 and B.C. 6000 , and the younger cluster includes two historical earthquakes of the A.D. 814 and A.D. 1850. Each cluster lasted about 1000-2000 years. A tranquil period of about 5000 years separates the two clusters, during which only one large magnitude earthquake occurred. Moreover, the average recurrence interval of large magnitude earthquake in the Holocene is about 1400-1700 years. Comparison of the maximum horizontal displacement of the A.D. 1850 earthquake, and the $85 \pm 5 \mathrm{~m}$ cumulative lateral offset over the last 13-15 ka gives the average recurrence interval of 1000-1360 years. The different estimates may arise because moderate and small earthquakes produced a quite high cumulative lateral displacement along the Zemuhe Fault during the Holocene.
\end{abstract}

Key words Holocene earthquakes - Zemuhe Fault Southwestern China

\section{Introduction}

The active Zemuhe Fault in Western Sichuan Province, China, is a part of a left lateral fault system, which is at least $1400 \mathrm{~km}$ long and extends northwest along the southeastern margin of the Tibetan plateau. This fault system (fig. 1, thick lines in insert), referred as the Kangding Fault System (e.g., Molnar and Tapponnier, 1978) or the Xianshuihe-Xiaojiang Fault Zone (e.g., Li, 1993; Wang et al., 1998), comprises five main

Mailing address: Dr. Honglin He, Institute of Geology, China Seismological Bureau, Beijing 100029, China; e-mail: honglinhe@hotmail.com faults: Ganzi Fault, Xianshuihe Fault, Anninghe Fault, Zemuhe Fault, and Xiaojiang Fault. These are amongst the most active faults in China, and clearly deserve comparison with other highly active strike-slip fault systems worldwide, such as San Andreas Fault in California, the North Anatolian Fault of Turkey, and Alpine Fault of New Zealand (Allen et al., 1991). Each of the main faults has accommodated at least one large historical earthquake. According to the local chronicles, the Zemuhe Fault produced two large earthquakes of $M \geq 7$ in A.D. 814 and A.D. 1850 (Huang, 1979; Gu, 1983; Chen, 1993a; Ren and Li, 1993).

Since the 1950's the neotectonics, seismogeology and seismicity of the Zemuhe Fault and in its surrounding area have been studied (e.g., Southwest Investigation Team of Earthquake Intensity, China Seismological Bureau, 1979), and the slip rate since the last glacial 


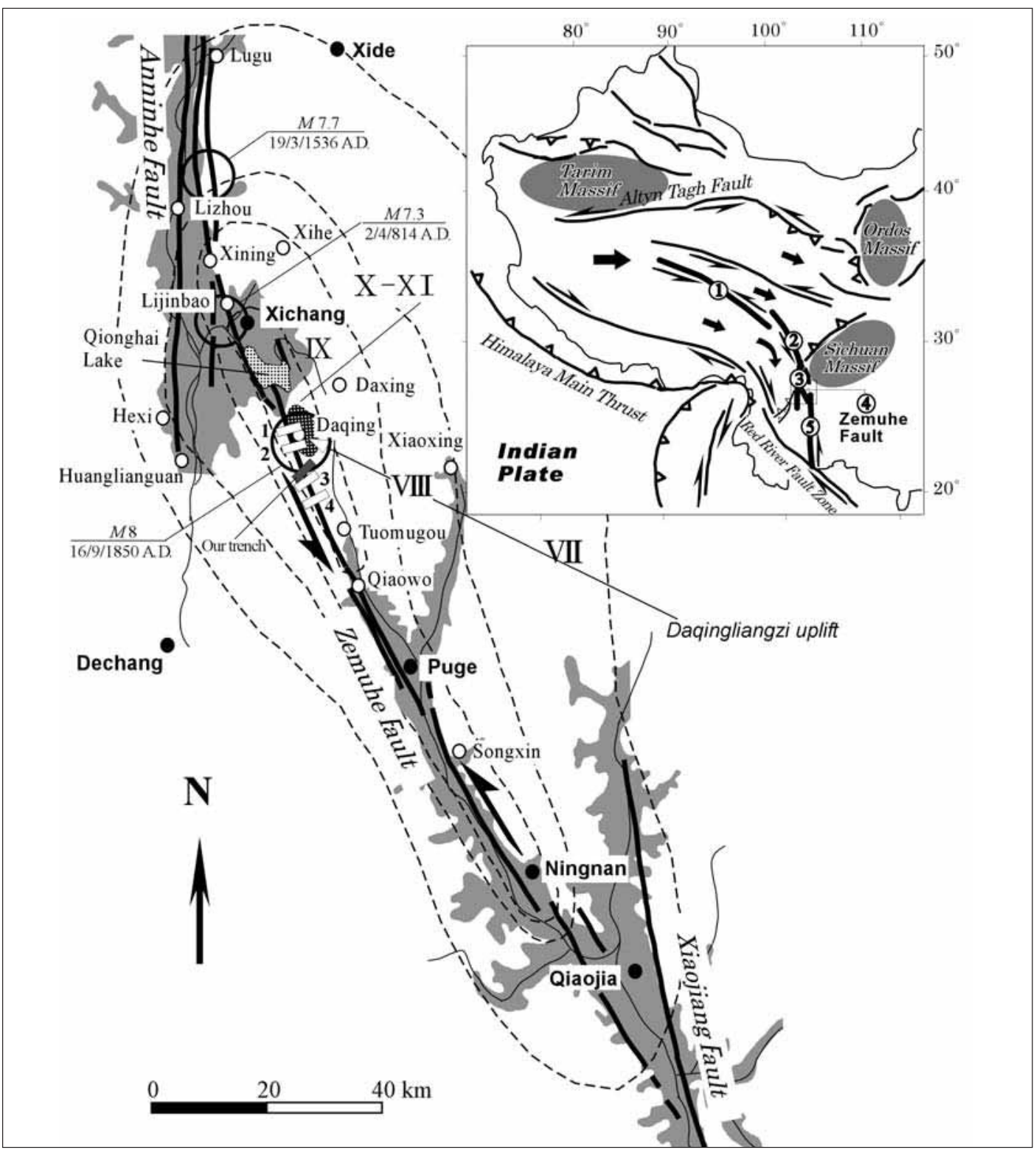

Fig. 1. Map of the Zemuhe Fault. Thick lines indicate the fault traces, large-unfilled circles are the epicenters of three historic earthquakes of $M \geq 7$ (Gu, 1983), and the dashed ovals show the isoseismal lines of the A.D. 1850 earthquake (Ren and Li, 1993). The unfilled rectangles across the Zemuhe Fault with numbers indicate the trench locations excavated by Fen et al. (1995), while the filled rectangle indicates the location of our trench. Inset box shows the sketch of Tibetan tectonics and the Zemuhe Fault Zone location. Thick line is the Kangding Fault System: 1) Ganzi Fault; 2) Xianshuihe Fault; 3) Anninghe Fault; 4) Zemuhe Fault and 5) Xiaojiang Fault. Wide arrows indicate the movement directions of crustal blocks within the Tibetan plateau, while thin arrows show the slip of faults. Data come from Li (1993). 
epoch for the Zemuhe Fault has been reasonably well constrained at $4.9 \mathrm{~mm} / \mathrm{yr}$ (Ren, 1986) or $5.8-8.6 \mathrm{~mm} / \mathrm{yr}$ (He et al., 1999). The active trace produced during the A.D. 1850 earthquake on the Zemuhe Fault was first recognized in 1985 (Ren and Li, 1989). Analysis of the faultscarp morphology suggests that the rupture length of this earthquake may have been $c a .30$ $\mathrm{km}$ (Chen, 1993a) or up to $90 \mathrm{~km}$ long (Ren and Li, 1993). Trenching across the fault by Fen $e t$ al. (1995) reveals 6 events during the Holocene, however, these data provide an incomplete record of earthquakes for this period of time. Here we use data from the displacement of dateable landforms and from trenches across the fault to constrain the earthquake history of the Zemuhe Fault. These data are combined with information from an exceptionally long historical record, and produce what we believe a complete data set of large magnitude earthquakes in the Holocene.

\section{Historical earthquakes}

On September 16th, A.D. 1850, a severe earthquake struck Xichang and its surrounding area, resulting in the deaths of more than 23526 people and significant damage to infrastructure (fig. 1) (Gu, 1983). The local chronicles show that two other large earthquakes of $M \geq 7$ also occurred in A.D. 814 and A.D. 1536 near Xichang, and these events can tentatively be correlated to the Zemuhe Fault (e.g., Huang, 1979; Chen, 1993a; Ren and Li, 1993). The A.D. 1536 earthquake may have occurred on the Anninghe Fault (fig. 1) (e.g., Chen, 1993b; Wen et al., 2000), while the epicenter of the A.D. 814 earthquake was located near the intersection of the Zemuhe and Anninghe faults $(\mathrm{Gu}, 1983)$. There is no strong geological evidence to suggest which of these two faults produced the A.D. 814 event. Based on historical records, most researchers preferred to locate it on the Zemuhe Fault (e.g., Ren and Li, 1989).

The epicenters of historical earthquakes in China are defined as the center of the meizoseismal area (Xie, 1957). The meizoseismal area is delineated based on the descriptions of earthquake damage recorded in local chronicles. Magnitude of historical earthquake is usually deduced from the seismic intensity in the meizoseismal area. Generally, both seismic intensity and magnitude can be estimated from historical records. Initially, the meizoseismal area of the 1850 earthquake was located at Xichang city, the intensity in the meizoseismal area was determined to be $\mathrm{X}$ on the New Chinese Seismic Intensity Scale (Xie, 1957), and the magnitude inferred to be 7.5 (Kunming Geophysics Institute, 1965 in Gu, 1983; Huang, 1979). The New Chinese Seismic Intensity Scale was made in 1957 and revised in 1980 based on the Modified Mercalli Scale in association with characteristics of Chinese buildings. The two seismic intensity scales are very similar. Historical records indicate that during the earthquake some damage occurred south of the Qionghai Lake, extending the meizoseismal area southeastward, and shifting the epicenter to between the Xichang and Ningnan (Lin and Gan, 1980). Furthermore, by reanalyzing historical earthquake records, Huang (1985) suggested the epicenter of this earthquake to be south of Xichang, with intensity in the meizoseismal area of $\mathrm{X}^{+}$on the Chinese Seismic Intensity Scale, and inferred the magnitude of this earthquake to be 7.7.

This earthquake not only produced damage to buildings and heavy loss of life, but also produced significant deformation of the ground surface, which was recorded in local chronicles more than 140 years after the earthquake the surface erosion had modified the active trace. However, many relics of this earthquake remain and can be identified in the field today. In 1985, the Research Group of Seismic Risk in Panxi Region, Sichuan Seismological Bureau identified a $30 \mathrm{~km}$ long rupture of this earthquake from south of Qionghai Lake to the Tuomugou (Chen, 1993a), and estimated the magnitude to be 7.5. In contrast, Ren and Li (1993) suggest a $90 \mathrm{~km}$ long rupture from Lijianbao to Songxin (fig. 2) with a maximum lateral displacement of $7 \mathrm{~m}$ (fig. 3), and a modified pattern of isoseismal lines (dashed ovals on fig. 1). They located the epicenter of the earthquake near the Daqing village, south of Qionghai Lake, and proposed $M 8$ based upon the rupture length and maximum displacement.

Based on our fieldwork in 1997 and 1998, we concur with the conclusions of Ren and Li (1993) for the reasons shown below. 


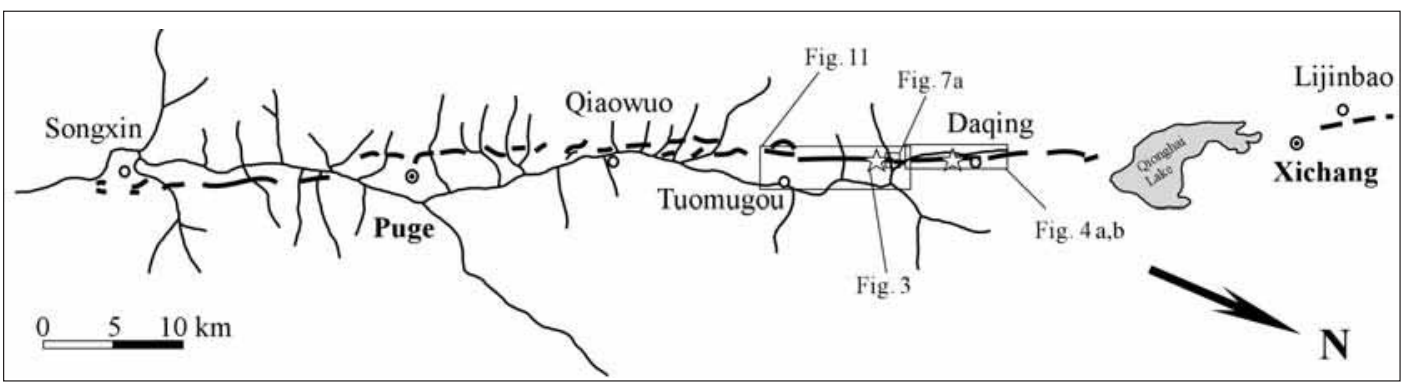

Fig. 2. Map of surface rupture associated with the A.D. 1850 earthquake. Thick lines show the location of the active trace, while the thin lines show the drainage of the Zemuhe River.

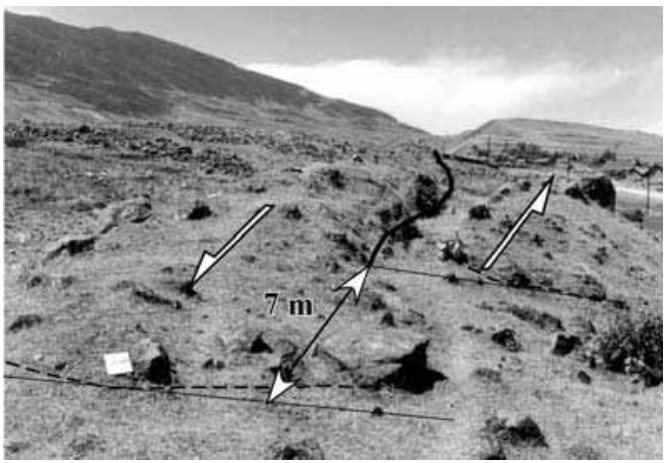

Fig. 3. Near the Sijiabushi village a $50 \mathrm{~cm}$ wide fissure due to the A.D. 1850 earthquake offset sinistrally a small pressure ridge by $7 \mathrm{~m}$, view to north.

1) We have identified a number of tectonic features between Daqing and Qiaowuo (figs. 1 and 2), such scarplets, fault trough, sag pond, offset landform, fissure and filled wedge, etc., as the landforms observed by Ren and $\mathrm{Li}$ in 1985 and 1986 (Ren and Li, 1993).

2) At Lijinbao village north of the Qionghai Lake (figs. 1 and 2), a fissure created in the A.D. 1850 earthquake, which is filled by a wedge of material, was described by Wu (1982). We named this kind of wedge-like filled material as filled wedge. Although no rupture phenomenon was found near the Xichang city presently, many landslides and fissures are recorded in the local chronicles. These fissures and landslides may be largely absent today because of intensive human activity, which has resulted in landform modification.

3) Near Songxin village (figs. 1 and 2) to the south a series of scarplets and tensional fissures were observed, which are arranged in a left-stepping en échelon pattern. The height of these scarplets ranges from $0.3 \mathrm{~m}$ to $6 \mathrm{~m}$, and the depth and width of these tensional fissures from $0.5-10 \mathrm{~m}$ and 1-10 m, respectively.

4) Along the rupture zone, lichen samples (Caloplaca sp. and Acarospora sp.), taken from the fault scarp or from talus in 9 sites including the scarplets and tensional fissures mentioned above, were dated at between $114 \pm 46$ and $164 \pm$ \pm 35 years BP (Ren, 1986). These data suggested that most of the observed fault-scarp was produced during the A.D. 1850 earthquake.

In addition to these two large historical earthquakes, there were 10 moderate earthquakes of $5 \leq M<7$ recorded on the Zemuhe Fault since A.D. $116(\mathrm{Gu}, 1983)$. Of these moderate size earthquakes, five events are between magnitude 5 and 6 , and the other five between magnitude 6 and 7 .

\section{Paleoearthquakes recorded by the offset of ravines along the fault scarp}

The Daqingliangzi uplift is the watershed between the Anninghe River Basin and the Zemuhe River Basin (fig. 1). Along the Zemuhe Fault, uplift has produced a $5 \mathrm{~km}$ long fault scarp (fig. 4a,b). The fault scarp reveals that the uplifted region comprises the Daqing Forma- 


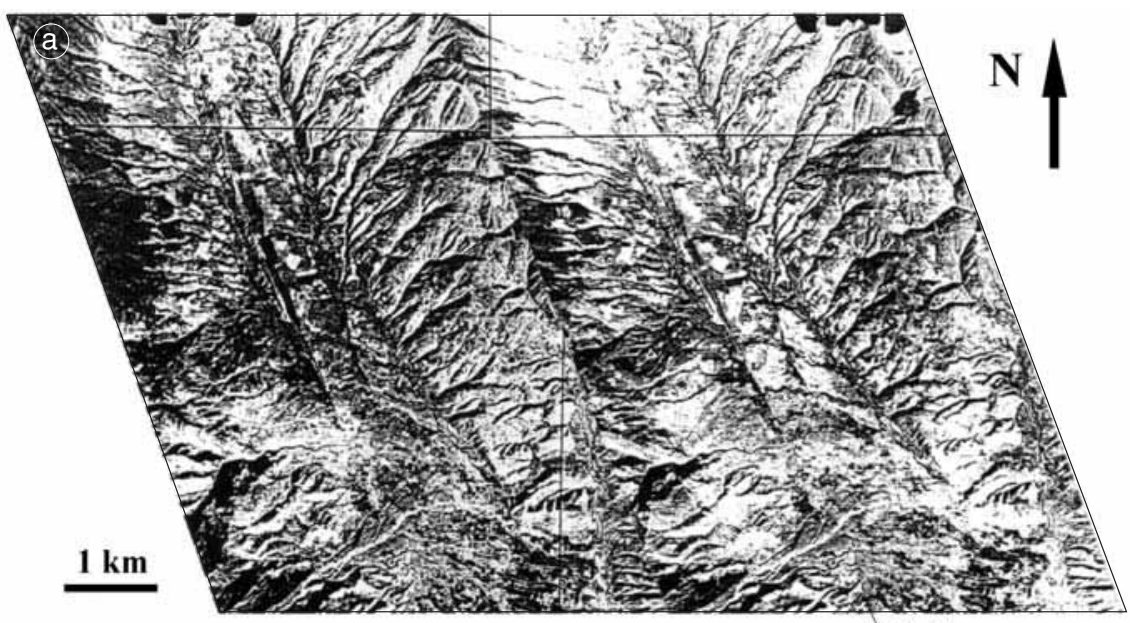

fault

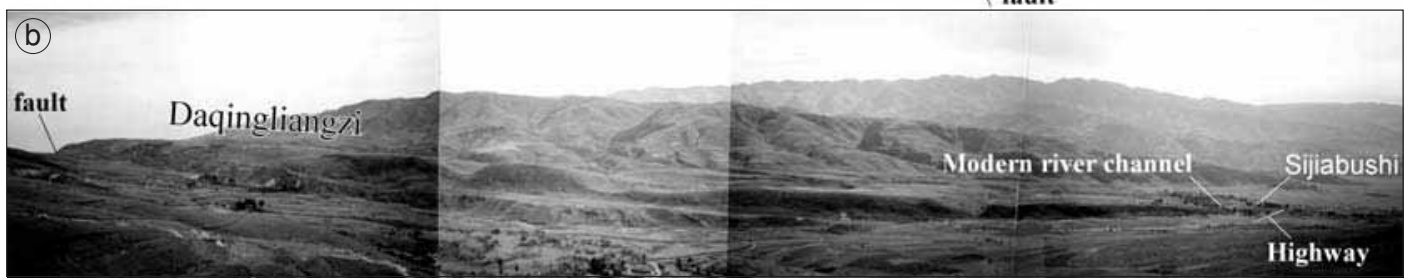

Fig. 4a,b. $5 \mathrm{~km}$ long fault scarp from Daqing to Sijiabushi (location shown in fig. 2). a) A pair of air photographs; b) field photograph, view to east.

tion gravel of Late Pleistocene age. Daqing Formation principally consists of pebbles derived from purple-gray quartz sandstone and rhyolite of Sinian age. The diameters of the pebbles vary between 18 and $35 \mathrm{~cm}$. The southeast dip of imbricated pebbles in the lower layer of the gravel suggests a paleo flow direction of Zemuhe River to the northwest towards Qionghai Lake in the early Late Pleistocene (Huang, 1979). It further suggests that the Daqingliangzi uplift started to grow no earlier than the Late Pleistocene. The height of the fault scarp decreases gradually from north to south, and diminishes at the bend in the highway near Sijiabushi (fig. 4b). In the north, the scarp height is about $40 \mathrm{~m}$ and its slope is about $50^{\circ}$, however, these values changes to $20 \mathrm{~m}$ and $70^{\circ}$ in the south. The $0.5-2 \mathrm{~m}$ high surface rupture produced by the A.D. 1850 earthquake developed along the base of the northern seg- ment of the fault scarp, and it merges with, and cannot be differentiated from, the fault scarp in the south.

Seven ravines are cut into the top of the Daqingliangzi uplift, on the upthrown eastern side of the fault scarp (figs. $4 \mathrm{~b}$ and 5). The average length of these ravines is about $1000 \mathrm{~m}$, and the width varies between 15 and $20 \mathrm{~m}$. Ren measured the geometry of the features of these ravines in 1986 (table I). We suggest that formation of the fault scarp not only resulted in abandonment of the ravines across the top of the Daqingliangzi uplift, but also separated the modern Zemuhe River into two branches. The eastern branch flows on the east of the uplift, whereas the western branch flows along the base of the fault scarp. East of the uplift all of these ravines are occupied by streams which flow southeastward into the eastern branch. West of the fault scarp on the downthrown wall 


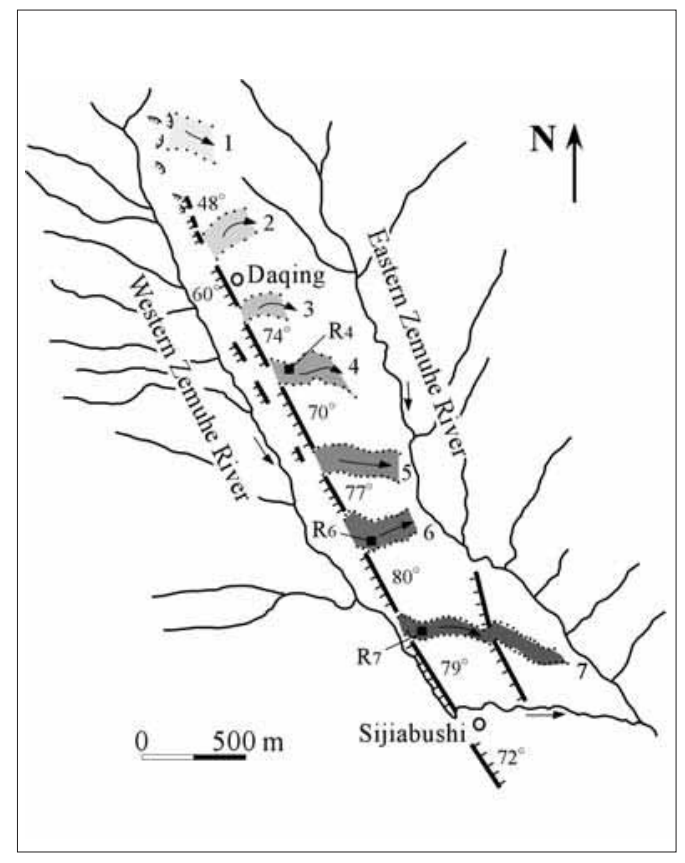

Fig. 5. Map of the fault scarp, offset ravines and drainage system on the top of the Daqingliangzi uplift. Thick line is the fault scarp with ticks on the downthrown side of the fault. Thin lines show the drainage system. Gray zones show the ravines; the grayscale from dark to light show the age of ravines from young to older. Arrows in the gray zones indicate the following directions. Black squares indicate the locations of the $\mathrm{C}^{14}$ samples. of the Zemuhe Fault, there are several minor streams flowing southeastward into the western branch (figs. 4a and 5). Ravines on the eastern, upthrown, side of the fault are all much deeper and wider than those on the downthrown wall, suggesting much greater flow in those ravines. Moreover, the ravines are all parallel to, and similar in shape to, the modern channel segment of the western branch north of Sijiabushi, which flows eastwards at the southern end of the fault scarp (figs. 4b and 5). These data suggest that the ravines were, in all probability, cut by the main channel segment of the western branch, and later we hypothesize that they were abandoned due to repeated uplift events on the fault.

The geomorphologic expression of these ravines indicates that the northern ravines are older than the southern ravines. The most direct expression is that slope angle and depth of the northern ravines are less than those of the southern ravines (table I). The three northernmost ravines ( 1 to 3 from north) on the Daqingliangzi uplift are subtle features and not easily identifiable. These ravines are shallow troughs with gentle (less than $10^{\circ}$ ) sideslopes, which are indicative of significant post-abandonment erosion of the ravines. The shape of the southernmost four ravines (4 to 7) is characterized by steep walls. The steep bank slopes of the southernmost four ravines also suggest that the ravines young from north to south (table I).

Table I. Slope angle of the bank and the depth of the seven ravines.

\begin{tabular}{ccccccccc}
\hline \hline & \multicolumn{3}{c}{ Southern slope } & & \multicolumn{3}{c}{ Northern slope } & \multicolumn{1}{c}{$D(\mathrm{~m})$} \\
& $A s$ & $L s(\mathrm{~m})$ & $H s(\mathrm{~m})$ & & $A n(\mathrm{~m})$ & $L n(\mathrm{~m})$ & $H n(\mathrm{~m})$ & $(H s+H n) / 2$ \\
\hline 1 & & & & & & & & \\
2 & $10^{\circ}$ & 61 & 10.6 & & $7^{\circ}$ & 45 & 5.5 & 8.1 \\
3 & $12^{\circ}$ & 64 & 13.3 & & $10^{\circ}$ & 39 & 6.8 & 10.1 \\
4 & $44^{\circ}$ & 31 & 21.5 & & $25^{\circ}$ & 17 & 7.2 & 14.4 \\
5 & $55^{\circ}$ & 30 & 24.6 & & $30^{\circ}$ & 22 & 11.0 & 17.8 \\
6 & $60^{\circ}$ & 15 & 12.9 & & $40^{\circ}$ & 30 & 19.3 & 16.1 \\
7 & $72^{\circ}$ & 14 & 13.3 & & $45^{\circ}$ & 21 & 14.9 & 14.1 \\
\hline
\end{tabular}

$A s$, and $A n$ are angles of the southern and northern slopes; $L s$, and $L n$ are lengths of the southern and northern slopes; $H s$, and $H n$ are heights of the southern and northern slopes, $H i=L i * \tan A i(i=s, n) ; D$ is the depth of ravine, $D=(H s+H n) / 2$. 
All of these ravines are cut into, and post date, gravel of the Daqing formation of Late Pleistocene age. A layer of yellow colored loess-like silt soil occurs on the top of the Daqingliangzi uplift. Since loess-like silt layer envelopes the three northernmost ravines, the Daqing formation gravel is not exposed. This suggests that the northernmost ravines 1-3 formed after deposition of the Daqing formation gravel and the change in flow patterns of the Zemuhe River, but before deposition of the loess-like layer. In the floor and sides of ravines 4-7 the Daqing formation gravel crops out and the gravel of the modern river is exposed and identified in the bottom of ravines 6 and 7. This suggests that ravines 4-7 must have formed after deposition of the loess-like silt.

We therefore propose that the ravines formed in sequence from north to south across the top of the Daqingliangzi uplift and that shifts in the position of the active stream channel were triggered by uplift during large magnitude earthquakes (fig. 6). In the early part of the Late Pleistocene, the Zemuhe River flowed northward into the Qionghai Lake (Huang, 1979), while in the latter part of the Late Pleistocene it changed its flow direction from northward to southward. After the change in river course, the Zemuhe River flowed as a single channel, flowing along the present-day eastern branch with a series of small tributaries flowing into the channel from each side. Formation of the fault scarp during large magnitude earthquakes resulted in the abandonment of small tributaries, which formally crossed the Daqingliangzi uplift. The water from these abandoned minor tributaries subsequently flowed southward along the base of the fault scarp, and produced the western branch of the Zemuhe River. The newly formed western branch changed flow direction from southward to eastward at the southern end of the fault scarp producing a new channel or occupying a preexisting minor tributary. During each large magnitude earthquake, the fault scarp extended southward, uplifting the area east of the fault and forcing western branch further south around the fault scarp. Simultaneously, the old eastward flowing segment of the western branch was uplifted and abandoned, producing a ravine immediately north of

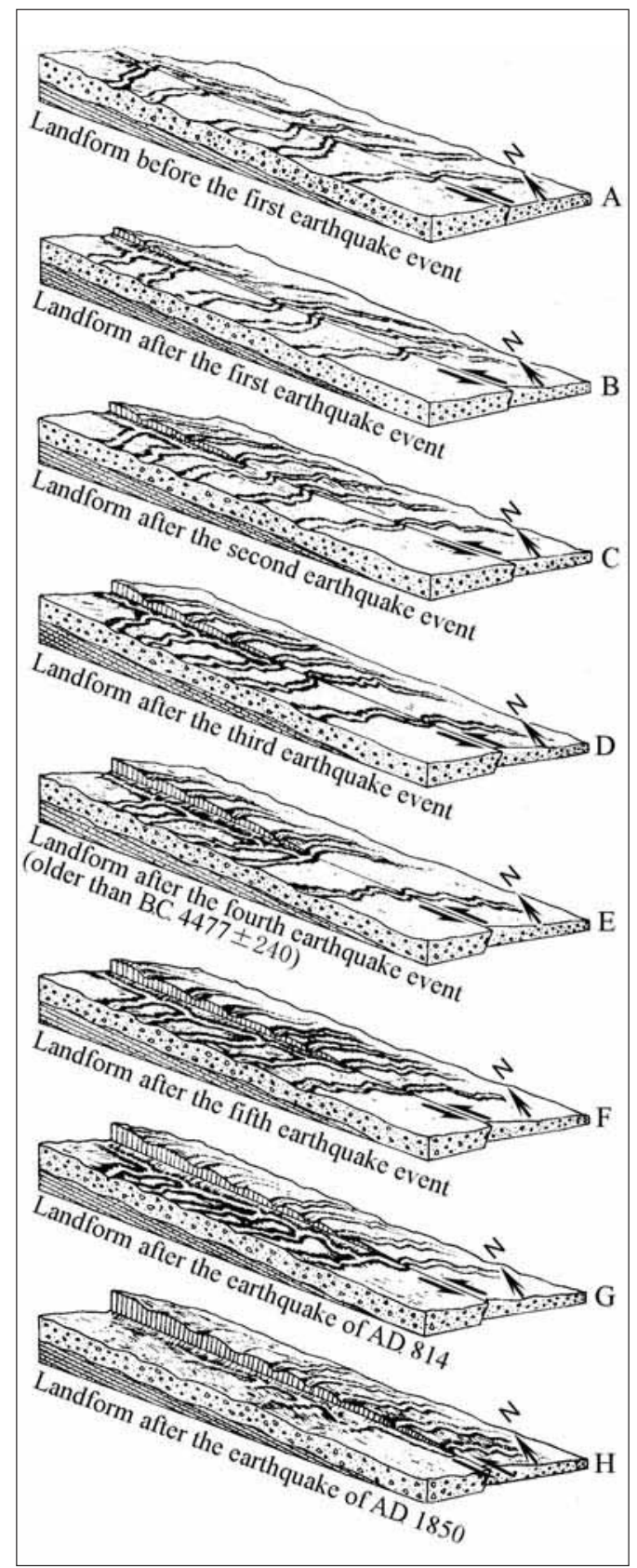

Fig. 6. Sketch showing the evolutionary scenario of ravines on the top of the Daqingliangzi uplift formed in association with large magnitude earthquakes on the Zemuhe Fault. 
the active channel. Therefore, the recurrence of large magnitude earthquake on the Zemuhe Fault is interpreted to produce the ravines on the top of the Daqingliangzi uplift (figs. $4 b, 5$ and 6). For such a model seven large magnitude earthquakes could produce the observed ravines.

The evolutionary model outlined above is consistent with the southward decrease in Daqingliangzi uplift. As a result, the fault scarp is a cumulative vertical displacement along the higher in north than in the south. We postulate that each ravine was abandoned due to episodic tearing of the fault during large magnitude earthquakes. Therefore, the time of abandonment of each ravine may indicate the date of each large magnitude earthquake. The dating of three $\mathrm{C}^{14}$ samples, taken in ravines 4, 6 and 7, implied the ages of three earthquakes corresponding to ravines 4,6 and 7 (table II, samples' location shown in fig. 5).

Of all of the ravines the southernmost one is the most similar in shape to the modern river channel at the southern end of the uplift. The difference between the two is that many trees and shrubs are growing on the two side-slopes of the latter, while the former contains many dead roots and trunks with little vegetation. These many dead roots and trunks in the southernmost ravine should have been growing before abandonment; their death is due to abandonment. A piece of a dead root (R7 in table II) taken from the floor of ravine 7 was radiocar- bon dated as younger than 200 years BP. Based on this date, we infer that ravine 7 was abandoned during the A.D. 1850 earthquake. At the floor of ravine 6 two hundred meters east of the fault scarp we observed a piece of paleo-flood plain. On the paleo-flood plain covers a layer of dark brown peat. We infer that the peat layer developed in a mash pond after abandonment. A sample (R6 in table II) taken from the dark brown peat layer was radiocarbon dated at $745 \pm$ \pm 85 years $\mathrm{BP}$, implying that this ravine was abandoned at some time older than A.D. $1279 \pm 123$. There is no historical record in local chronicles of an earthquake in this region near A.D. $1279 \pm$ \pm 123 . We consider it unlikely that an earthquake of the magnitude as large as the A.D. 1850 event would not be recorded in local chronicles had it occurred near A.D. $1279 \pm 123$. Therefore, we hypothesize that ravine 6 was abandoned during the A.D. 814 earthquake and that the young radiocarbon age may indicate that some of the dated carbonaceous material accumulated in the ravine well after abandonment. Near the fault scarp on the base of northern convex slope of ravine 4 found a layer of black peat, which has been radiocarbon dated at $5615 \pm 115$ years BP (R4 in table II). Also considering the black peat layer developed in a mash pond in the ravine after abandonment, we can infer another earthquake event have occurred at, or older than B.C.

Table II. Radiocarbon data.

\begin{tabular}{|c|c|c|c|c|c|}
\hline No. & Location & Material & $\mathrm{C}^{14}$ age (years BP) & Cal age $(\mathrm{yr})^{\#}$ & Lab. \\
\hline R7 & Ravine 7 & A piece of wood & $<200$ & < A.D. 1750 & Lab. $1\left(^{1}\right)$ \\
\hline R6 & Ravine 6 & Peat & $745 \pm 85$ & A.D. $1279 \pm 123$ & Lab. $1\left(^{1}\right)$ \\
\hline $\mathrm{R} 4$ & Ravine 4 & Peat & $5615 \pm 115$ & B.C. $4477 \pm 240$ & Lab. $1\left(^{1}\right)$ \\
\hline Tro-1 & Our trench & A piece of wood & $3150 \pm 100$ & B.C. $1422 \pm 216$ & Lab. $1\left({ }^{2}\right)$ \\
\hline $\operatorname{Tr} 1-1$ & Trench 1 & Wood fragments & $500 \pm 100$ & A.D. $1412 \pm 119$ & Lab. $2\left({ }^{3}\right)$ \\
\hline $\operatorname{Tr} 1-2$ & Trench 1 & Wood fragments & $1200 \pm 120$ & A.D. $828 \pm 211$ & Lab. $2\left({ }^{3}\right)$ \\
\hline $\operatorname{Tr} 1-3$ & Trench 2 & Peat & $3612 \pm 106$ & B.C. $1969 \pm 243$ & Lab. $2\left({ }^{3}\right)$ \\
\hline $\operatorname{Tr} 2-1$ & Trench 2 & Peat & $5528 \pm 95$ & B.C. $4386 \pm 167$ & Lab. $2\left({ }^{3}\right)$ \\
\hline $\operatorname{Tr} 3-1$ & Trench 3 & Wood fragments & $670 \pm 145$ & A.D. $1259 \pm 235$ & Lab. $2\left({ }^{3}\right)$ \\
\hline $\operatorname{Tr} 3-2$ & Trench 3 & Peat & $6700 \pm 155$ & B.C. $5602 \pm 244$ & Lab. $2\left({ }^{3}\right)$ \\
\hline $\operatorname{Tr} 3-3$ & Trench 3 & Peat & $12015 \pm 216$ & B.C. $11979 \pm 462$ & Lab. $2\left({ }^{3}\right)$ \\
\hline $\operatorname{Tr} 3-4$ & Trench 3 & Wood fragments & $4993 \pm 137$ & B.C. $3778 \pm 270$ & Lab. $2\left({ }^{3}\right)$ \\
\hline
\end{tabular}

Lab. 1 - New Date Laboratory, Institute of Geology, CSB; Lab. 2 - Sichuan Seismological Bureau. " - Calculated by CALIB Radiocarbon Calibration (Vision 4.3). ( $\left.{ }^{1}\right)$ Ren (1986); $\left({ }^{2}\right)$ this study; $\left({ }^{3}\right)$ Fen et al. (1995). 
$4477 \pm 240$. In addition to the three inferred events occurred at A.D. 1850, A.D. 814 and B.C. $4477 \pm 240$ or older, four more events might be indicated by the observed ravines. For such a scenario the large magnitude earthquake that resulted in abandonment of ravine 5 would date at between A.D. 814 and B.C. $4477 \pm 240$. The remaining three ravines are inferred to be older than B.C. $4477 \pm 240$, and also older than the loess-like silt. The silt has not been dated and we suggest that ravines 1-3 are most likely to be early Holocene in age. This would require seven large magnitude earthquakes on the Zemuhe Fault in the last $10 \mathrm{kyr}$.

\section{Paleoearthquakes recorded in trenches}

Five hundred meters south of the southern end of the fault scarp a stream is offset in a leftlateral sense by about $85 \mathrm{~m}$. On the eastern side of the fault the stream has been abandoned and formed a relict tail-cut stream. A new alluvial fan has formed on the eastern side of the fault and a small gully has been displaced left-laterally by $16 \mathrm{~m}$ (fig. 7a). North of the abandoned tailcut stream a small pressure ridge is developed on the eastern side of the fault (fig. 7b), probably due to a slight right step of the fault traces. North of the small pressure ridge, we excavated a $10 \mathrm{~m}$ long, $1.5 \mathrm{~m}$ wide and $2.5 \mathrm{~m}$ deep trench (location shown by a filled box across the Zemuhe Fault in fig. 1, and a unfilled box in fig. $7 b$ ). Based on mapping of the trench the log was divided into 15 units (fig. 8).

This trench revealed two earthquakes of the Zemuhe Fault. It is, however, difficult to identify the displacement of each event, because no sedimentary layers could be correlated across the fault surface on the trench log. The wedge deposits of unit 2 and unit 8 are likely to indicate the two seismic events. Figure 9 presents a possible scenario of the events in the trench. The older event displaced and flexed sediments of unit 10 to unit 15 (stage 2). After this event, a colluvial wedge (unit 8) was deposited in the depression formed by the flexure. The younger event cut this colluvial wedge and dragged the peat sediment of unit 7 down (stage 4). Another wedge deposition (unit 2) was formed after the second event.

A piece of wood (Tro-1 in table II) enclosed by sediments of unit 11 to unit 14 was radiocarbon dated at $3150 \pm 100$ years BP. This dating result indicates that unit 11 is, or older than B.C. $1422 \pm 216$. The fault trace does not reach the ground surface, and the sediments of units 2 to 6 are not displaced. Moreover, the $90 \mathrm{~km}$ long surface rupture of the A.D. 1850 earthquake was found to go through east of the trench along the fault scarplet (fig. 7b; Ren, 1986). We therefore infer that the two events interpreted in this trench should have occurred in the period between B.C. $1422 \pm 216$ and the A.D. 1850 earthquake, and the younger one may be consistent with the A.D. 814 earthquake.

On the same section of the fault that we trenched, Fen et al. (1995) excavated four trenches in 1995 (locations shown in fig. 1, unfilled boxes across the Zemuhe Fault with numbers). Because the timing of paleo-events in the southernmost trench was not constrained by dating (trench 4), we only use data derived from the remaining three trenches.

Trench 1 was excavated north of the Daqing village across the fissure zone formed in the A.D. 1850 earthquake. This trench revealed a multifissure zone, which is filled by three wedges of different materials. Two $\mathrm{C}^{14}$ samples of wood fragments (Tr1-1 and $\operatorname{Tr} 1-2$ in table II) taken from the two youngest filled wedges produced dates of $500 \pm 100$ years BP and $1200 \pm 120$ years BP. The newest stratum, which is cut by the boundary fault of the oldest filled wedge, is $c a$. $1.5 \mathrm{~m}$ thick light yellow sediment of silt with pebbles. In the middle of the stratum there is a thin peat layer of $c a .1 .75 \mathrm{~m}$ long and $5 \mathrm{~cm}$ thick, which was radiocarbon dated at $3612 \pm$ \pm 106 years BP (Tr1-3 in table II). If the three filled wedges resulted from three seismic events, the three seismic events should all be younger than B.C. $1969 \pm 243$. If the wood fragments taken from the two youngest filled wedges died prior to being incorporated into the wedges, the event corresponding to the newest filled wedge should be the A.D. 1850 earthquake (younger than A.D. $1412 \pm 119$ ), and the event corresponding to the middle filled wedge should be A.D. $828 \pm$ \pm 211 , which is consistent with the historical 


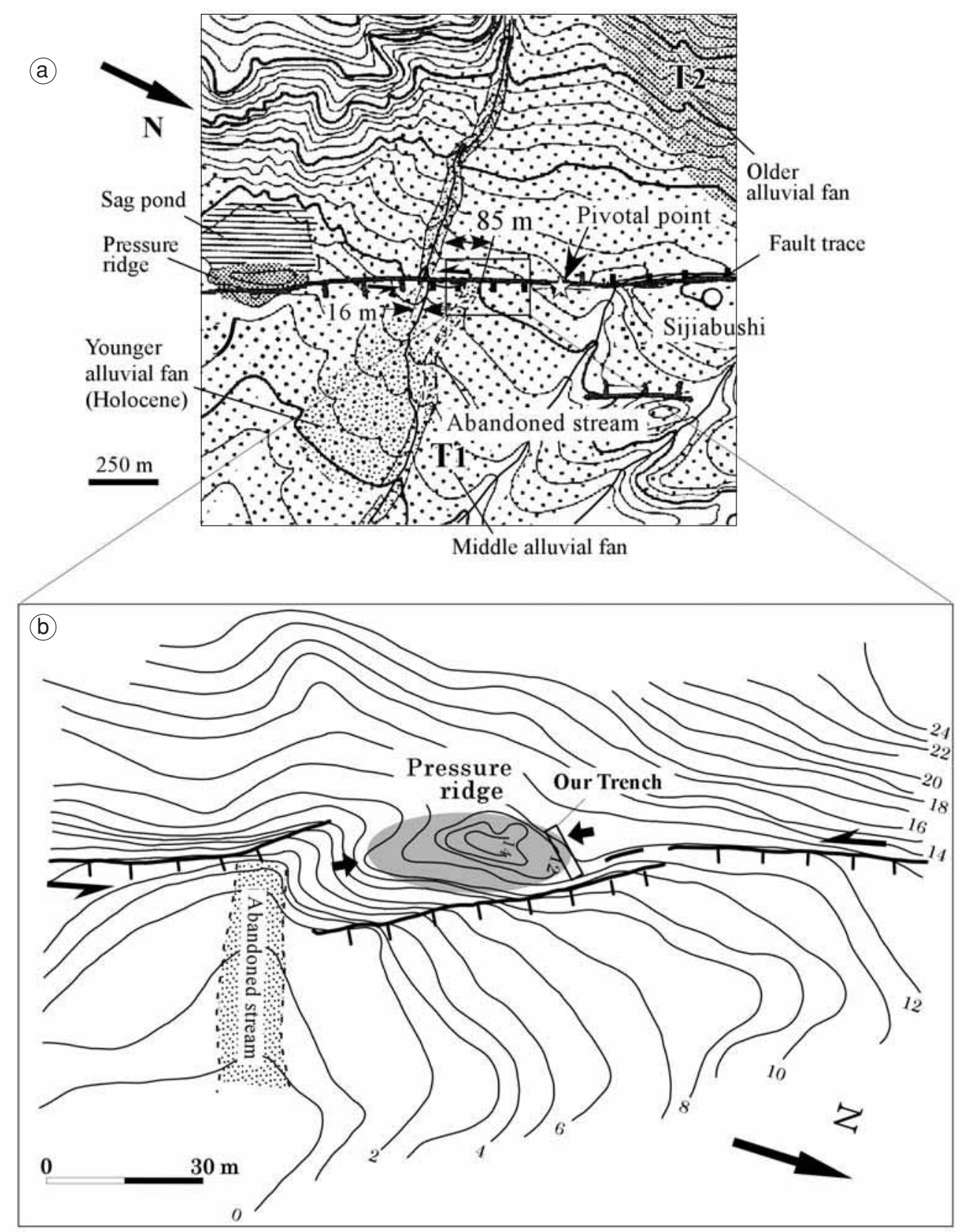

Fig. 7a,b. a) Geomorphologic map of Zemuhe Fault (location shown in fig. 2). Fault scarp is marked by the thick line; ticks are on the downthrown side of the fault. Eighty-five-meter lateral displacement of abandoned stream is shown. Contour data (10 m intervals) are from 1:50000 topographic maps. b) Detailed map of part of fault. Topographic contours of $1 \mathrm{~m}$ were constructed from surveying and the thick lines with teeth show fault scarplet and the rupture of the A.D. 1850 earthquake. 


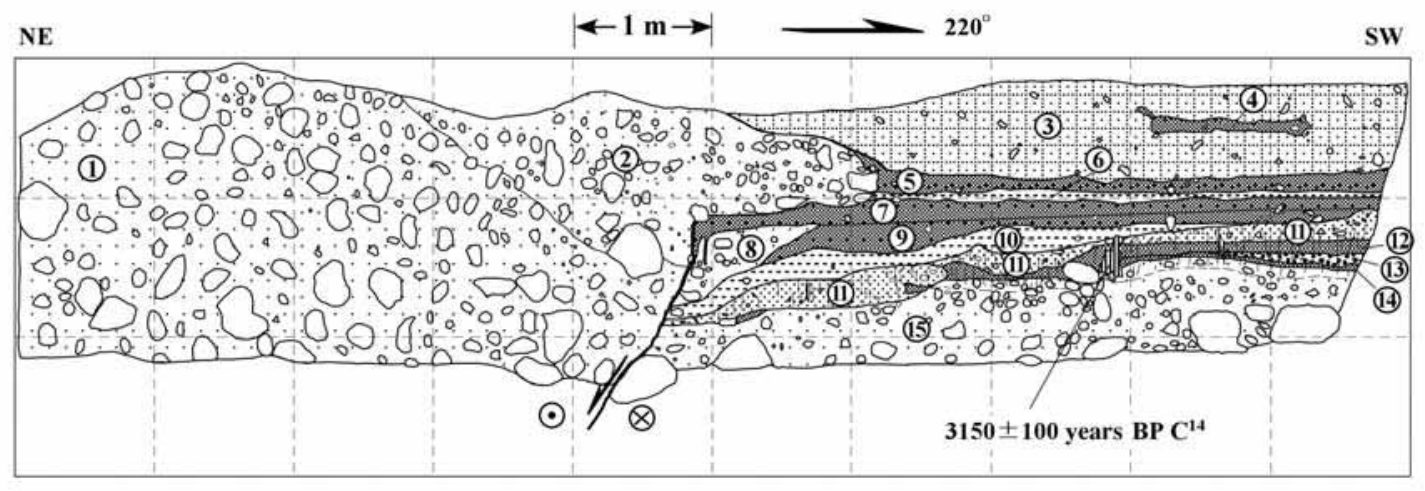

Fig. 8. Log of the southern wall of the trench excavated by us for this study. The location of the trench is shown in figs. 1 and 7b. 1 - Light yellow boulder gravel bed; 2 - mixed deposit wedge of gray soil and gravel; 3 - dark brown soil used for cone cultivation; 4 - black peat lens in unit 3; 5 - black peat bed; 6 - brown humus-rich silt bed; 7 - black peat bed; 8 - deposit wedge of sand gravel; 9 - black peat bed like unit 7, but having poor stratification; 10 - dark brown humus-rich silt bed, thicker than unit 6;11 - light yellow gravel sand bed with rich pieces of root and root hair; 12 - black peat with rich pieces of root and root hair; 13 - yellow sand bed with rich pieces of root and root hair; 14 - dark brown humus-rich silt bed with rich pieces of root and root hair; 15 - gray gravel-bearing sand bed, its top layer has rich pieces of root and root hair.

earthquake of A.D. 814. The oldest event recorded in this trench must be younger than B.C. $1969 \pm 243$. These conclusions are similar to inferences from our trench (fig. 8).

Trench 2 crossed a scarplet of the A.D. 1850 earthquake. This trench revealed five fault surfaces (F1, F2, F3, F4, and F5) and a colluvial wedge. Although Fen et al. (1995) proposed that there are five seismic events recorded in this trench, only four of these events, including the 1850 earthquake, are unambiguously represented (fig. 10). The oldest event is indicated by $\mathrm{F} 1$, which is covered by the colluvial wedge. The sediment layer displaced by F1 was dated at $5528 \pm 95$ years BP using a sample of peat taken from this layer (Tr2-1 in table II). This implies that the oldest event is younger than B.C. $4386 \pm 167$. The colluvial wedge, which occurs in the northeast of F2 and covers F1, demonstrates an earthquake younger than the oldest event. A sediment layer was deposited over the colluvial wedge and F2, F3. The fault surface F4 cut into this sediment layer and indicates another event younger than the two events noted above. The newest event is the A.D. 1850 earthquake that produced a modern scarplet (F5) and a sag pond northeast of the scarplet.
Trench 3, which is about $100 \mathrm{~m}$ south of our trench, also crossed a fissure of the 1850 earthquake. Fen et al. (1995) identified six events in this trench, but in our opinion two of these events are equivocal. The remaining four events in this trench will be summarized here (fig. 10). A multi-fissure zone filled by two wedges of different materials and two fault surfaces (F1 and F2) within the trench we interpreted to have formed in four earthquakes. The younger filled wedge is composed of yellow sandy silt, from which a sample of wood fragments (Tr3-1 in table II) was dated to be $670 \pm 145$ years BP. Considering that the wood fragments possibly died hundreds of years prior to being incorporated into the wedge, we infer that the younger filled wedge formed after the A.D. 1850 earthquake (much younger than A.D. $1259 \pm 235$ ). The older filled wedge is composed of gray sandy silt including some pebbles. A sample of peat taken from the older filled wedge (Tr3-2 in table II) was dated to be $6700 \pm 155$ years BP. This radiocarbon date demonstrates another earthquake occurred at B.C. $5602 \pm 244$ or older. The event indicated by the fault surface $\mathrm{F} 1$ is the oldest one revealed in this trench. A peat sample ( $\operatorname{Tr} 3-3$ in table II) taken from the 
Stage 5

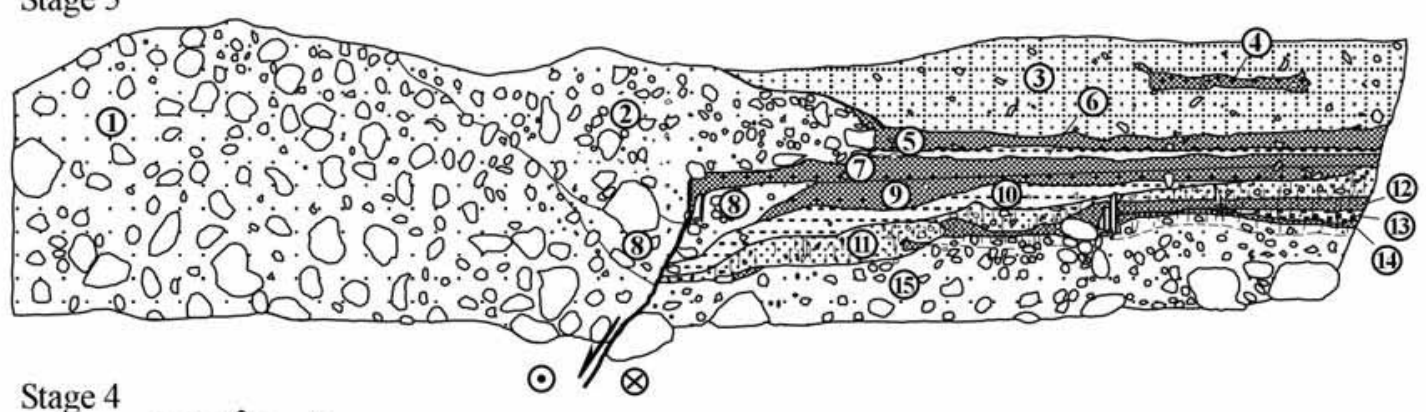

Stage 4

$\odot$

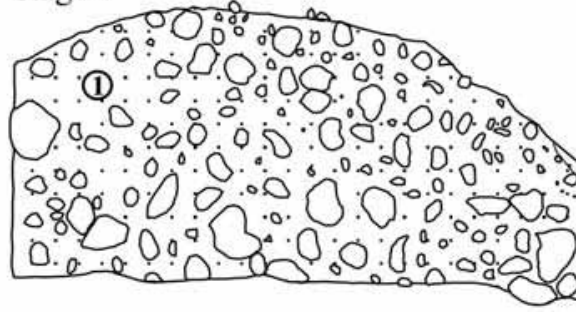

Stage 3
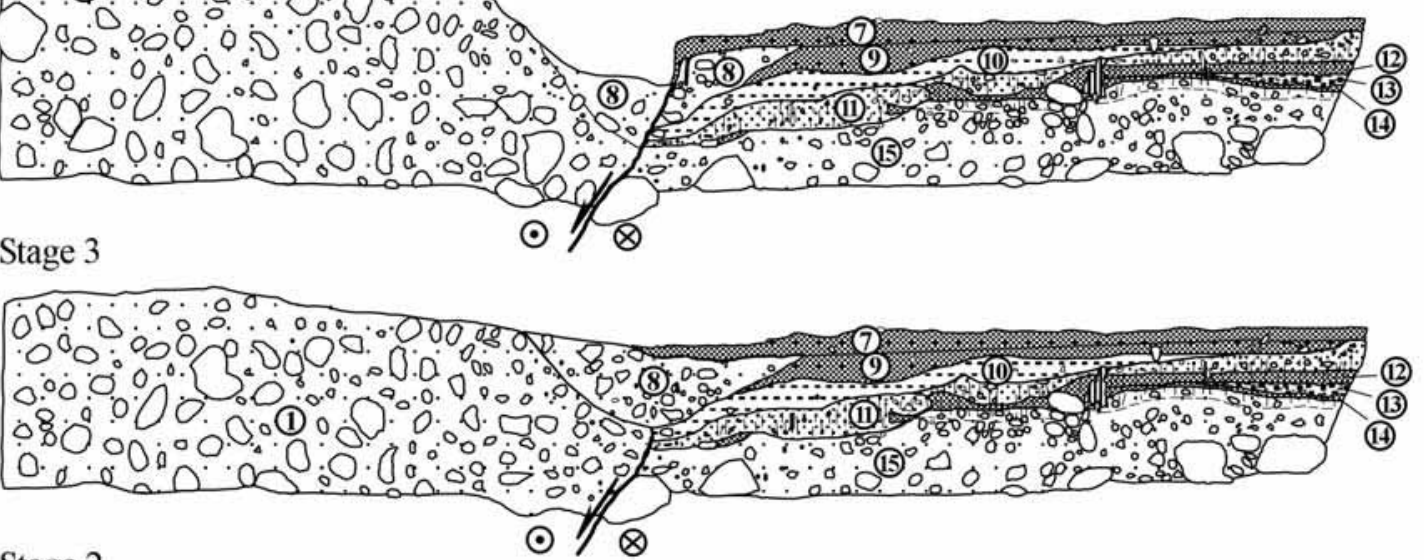

Stage 2

$\odot V_{\otimes}$

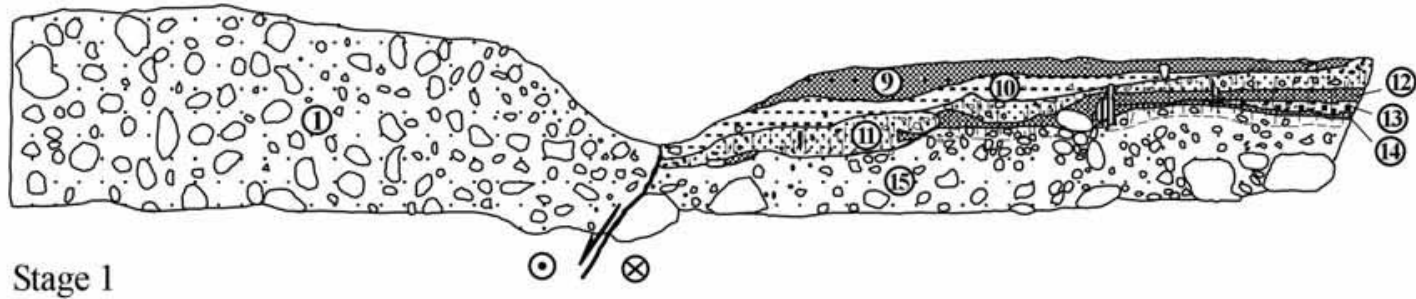

\section{Stage 1}

$\odot \gg$

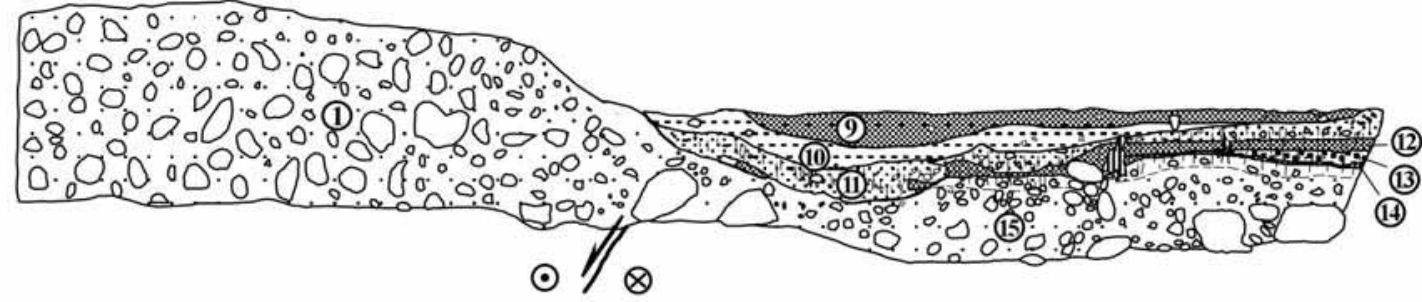

Fig. 9. A possible history for the trench in fig. 8 , giving 5 stages, in which stage 2 and stage 4 correspond to two large magnitude earthquakes. 


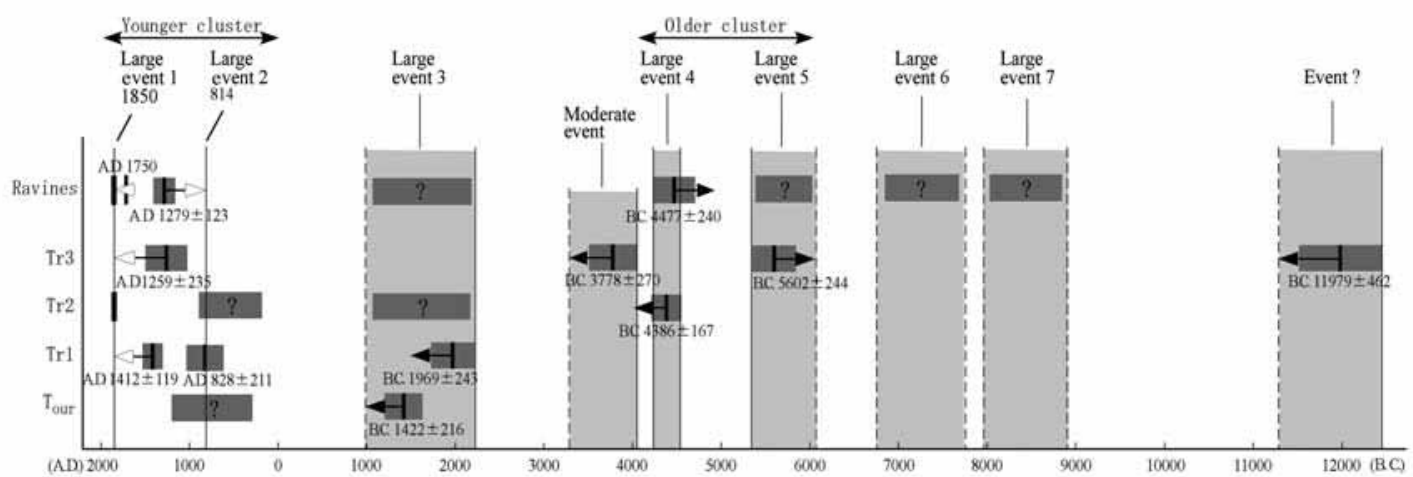

Fig. 10. Seismological history of the Zemuhe Fault based upon historic and paleoseismological data. $\operatorname{Tr} 1, \operatorname{Tr} 2$ and $\operatorname{Tr} 3$ are three trenches excavated by Fen et al. (1995), $T_{\text {our }}$ is the trench excavated by us in 1997. Arrow with left direction show the upper age limit of paleoearthquakes, while arrow pointing rightwards indicates the lower age limit of paleoearthquake. The unfilled arrow indicates that the seismic event dated by radiocarbon sample is actually a historical earthquake. Dark gray rectangles show the errors on the radiocarbon dating. Question marks within dark gray rectangles indicate an inferred paleoearthquake without dating. Double-arrow shows temporal cluster of seismic activity. Light gray rectangles show preferred ages for the paleoearthquakes; thin vertical lines shows possible age bound of the paleoearthquake, while dashed line shows no age bound of the paleoearthquake.

surface of F1 was dated to be $12015 \pm 216$ years BP. If inferring that the peat formed in surrounding sediment before and was drawn onto the surface of F1 during this oldest earthquake, the oldest event should be younger than B.C. $11979 \pm 462$. Another layer of sandy gravel deposited over the fault surface F1 was cut by another fault surface F2. This sandy gravel was dated to be $4993 \pm 137$ years BP using wood fragments (Tr3-4 in table II) taken from the gravel. The event indicated by F2 should be therefore younger than B.C. $3778 \pm 270$.

\section{Discussion}

The radiocarbon dates indicate four large magnitude earthquakes since some time older than B.C. $4477 \pm 240$, which were associated with the formation of the southernmost four ravines (4-7). The trench we excavated recorded two earthquakes, probably in the period from B.C. $1422 \pm 216$ to A.D. 1850 , in addition to the latest historic earthquake of A.D. 1850. The three trenches excavated by Fen et al. (1995) suggest three, four and five events. We summarize these results as in fig. 10.

Although the trench data are incomplete in the Holocene, it is likely that the seven events for the ravines include all large magnitude earthquakes as strong as the A.D. 1850 earthquake or A.D. 814 earthquake. Of the seven large magnitude earthquakes, the trenches reveal the youngest five. The paleoearthquake younger than B.C. $3778 \pm 270$ revealed in trench 3 is an independent event, no relation to any large event indicated by ravine data (fig. 10). Considering the inference that the seven events for the ravines are all large magnitude earthquakes of the Zemuhe Fault in the Holocene, we suggest this paleo-event younger than B.C. $3778 \pm 270$ is a moderate earthquake. Moreover, trench 3 recorded a Late Pleistocene earthquake younger than B.C. $11979 \pm 462$. Seven large magnitude earthquakes indicated by ravine data suggest an average recurrence interval of large magnitude earthquakes on the Zemuhe in the Holocene of about 1400-1700 years. However, collectively the trench and ravine data indicate that the recurrence interval of large magnitude earthqua- 
kes in the Holocene along the Zemuhe Fault is not uniform (fig. 10). Except for the oldest two Holocene large paleoearthquakes with no radiocarbon date, the remaining five large radiocarbon-dated events present obviously two temporal clusters. The older cluster occurred between B.C. 4250 and B.C. 6000 including two large magnitude earthquakes (large events 4 and 5), and the younger cluster since A.D. 814 including historical earthquakes of A.D. 1850 and A.D. 814. The recurrence interval in the older cluster is similar to the average, 1400-1700 years, while the recurrence interval in the younger cluster is only 1000 years, shorter than the average. The two temporal clusters are separated by a tranquil period of about 5000 years, during which only one large magnitude earthquake (large event 3 ) occurred.

The majority of Quaternary sediments in the Zemuhe River valley deposited during deformation were derived from a local source. Local transport of these sediments resulted in the formation of three river terraces the Zemuhe River valley $\left(T_{1}, T_{2}\right.$, and $T_{3}$ from low to high). The most extensive terrace is the lowest $\left(\mathrm{T}_{1}\right)$ (fig. 11), which consists of a unitary deposit of boulder gravel with a sand and mud matrix. The sizes of framework boulders range from several centimeters to several meters. This gravel is polymictic, comes mainly from the following sources: 1) Sinian-age purple sandstone, tuff, conglomerate, and gray dolostone and limestone; 2) Triassic-age gray quartz sandstone and limestone, and 3) Jurassic-age purple sandstone. Fresh exposures of the gravel are light purple because most of the source rocks are purple. A silt and fine sand sample, taken from the lowest terrace (about $1 \mathrm{~m}$ deep), has been dated at $13290 \pm 104$ years BP using a thermoluminescence method (He et al., 1999). Ren (1986) radiocarbon dated a piece of wood in the terrace deposit to be $15630 \pm 990$ years BP. Therefore, the lowest terrace $\left(\mathrm{T}_{1}\right)$ is estimated to have in the last glacial epoch, about 10-15 kyr BP. Between Sijiabushi and Tuomugou, we have measured five offsets of streams or creeks at four sites ( $85 \mathrm{~m}, 88 \mathrm{~m}, 80 \mathrm{~m}, 90 \mathrm{~m}$ and $80 \mathrm{~m})$, which are

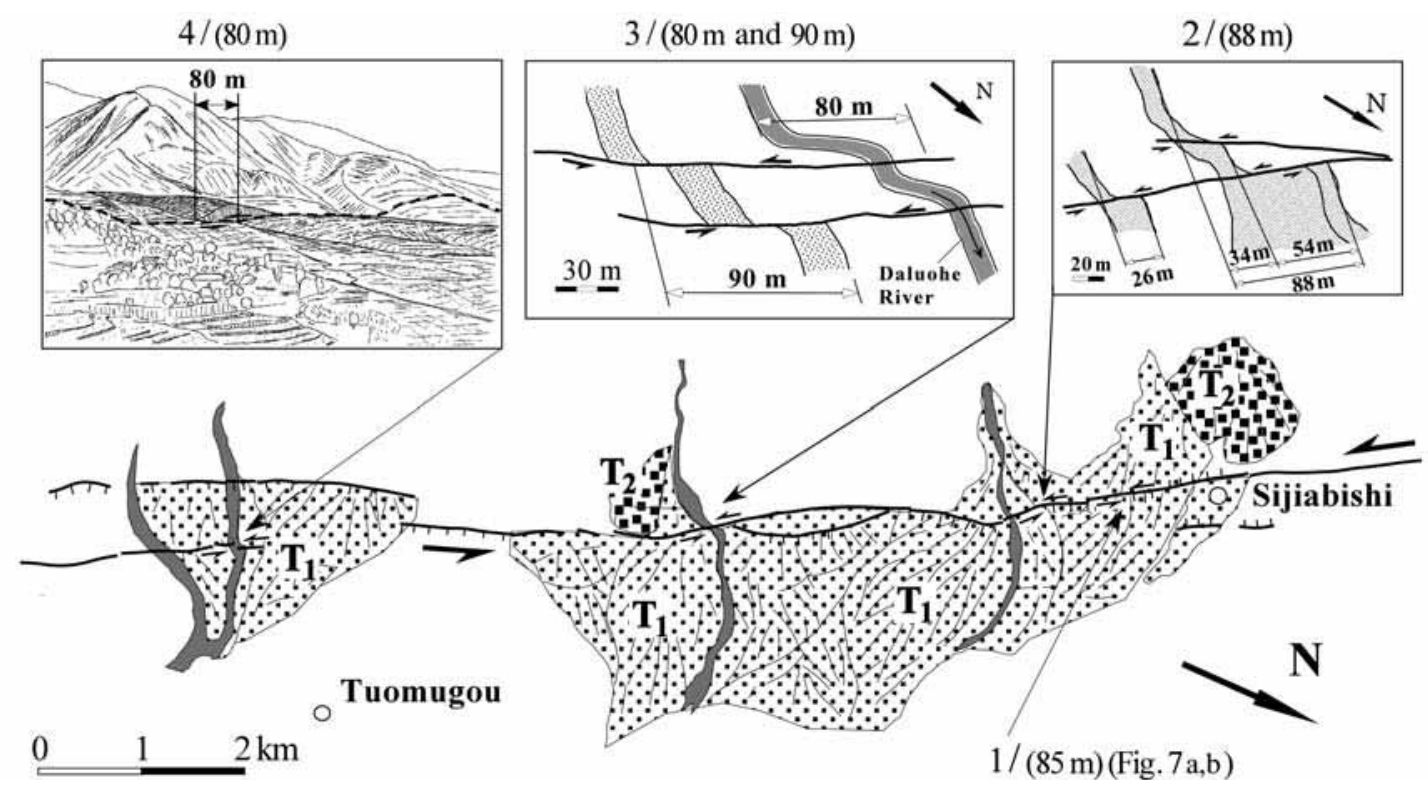

Fig. 11. Map showing the fault trace and terraces of the alluvial fan in the Zemuhe Valley between Sijiabushi and Tuomugou. Five offsets of streams developed on the alluvial fans of the first terrace $\left(\mathrm{T}_{1}\right)$ have been measured at four sites. Three boxes above show detailed offsets of streams. 
cut into the lowest terrace ( $\left.\mathrm{T}_{1}\right)$ (fig. 11). Therefore, the average $85 \pm 5 \mathrm{~m}$ offset is younger than the formation of the lowest alluvial fan terrace, and was produced by a series of earthquakes since the last glacial epoch. The maximum lateral displacement in the A.D. 1850 earthquake was identified to be $7 \mathrm{~m}$ (fig. 3). Eleven to thirteen large magnitude earthquakes with lateral displacement of $7 \mathrm{~m}$ would be required to produce $85 \pm$ $\pm 5 \mathrm{~m}$ cumulative offset. The average recurrence interval would be $1000-1360$ years. This result is shorter than 1400-1700 years estimated by historic earthquakes and dated paleoearthquakes.

Regardless of the error of the radiocarbon dating, the fact remains that quite a high part of total accumulated displacement along the Zemuhe Fault was probably not produced by large magnitude earthquakes. We infer that quite a large part of total accumulated displacement along the Zemuhe Fault was accommodated by moderate and small earthquakes. According to the local chronicles, 10 moderate earthquakes of magnitude between 5 and 7 have occurred on the Zemuhe Fault since A.D. 116 (Gu, 1983). Trench 3 reveals a moderate paleoearthquake younger than B.C. $3778 \pm 270$, which should have produced surface rupture. The Xiaojiang Fault, another active fault of the Kangding Fault System as the Zemuhe Fault (inset in fig. 1), has similar features. The average recurrence interval estimated using the rate of strike slip is less than that estimated from paleoearthquake data (Shen et al., 1997). Shen et al. (1998) proposed a model similar to ours to explain this kind of difference of recurrence intervals.

Table I shows the geometric features of those ravines on the top of the Daqingliangzi uplift. The depths of the ravines are all greater than the 5 m maximum vertical displacement of the 1850 earthquake (Ren, 1986) and the depths of the Zemuhe River channel or other nearby streams. This suggests much stronger river erosion on the Daqingliangzi uplift than nearby area. We infer the much stronger river erosion is caused by the vertical displacement of the Daqingliangzi uplift during those moderate earthquakes. Therefore, we improve the evolutionary model proposed above as fig. 6 shows. Initially, the Western Zemuhe River channel flowed southward along the fault scarp and turned to

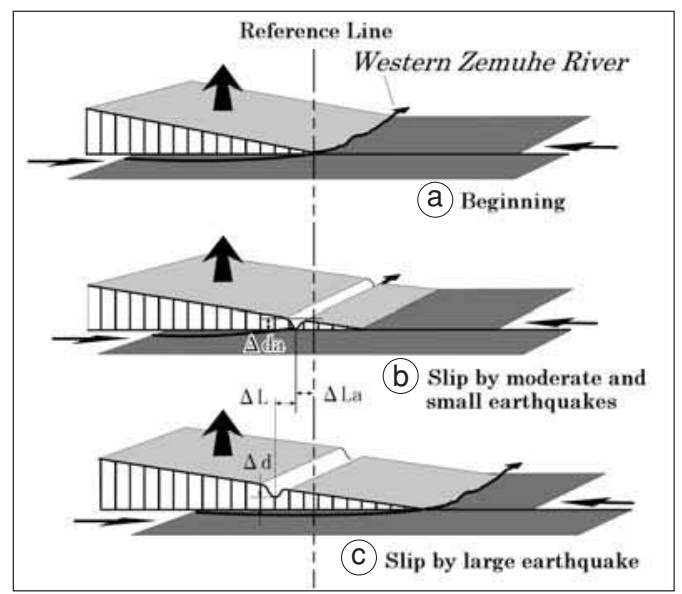

Fig. 12a-c. Model to illustrate the development the Daqingliangzi fault scarp and ravines on the scarp top. $\Delta L$ and $\Delta d$ are the horizontal and vertical offsets during large magnitude earthquakes; $\Delta L a$ and the depth of the abandoned ravine $\Delta d a$ are the horizontal and vertical offsets accommodated by moderate and small earthquakes.

east around the southern end of the fault scarp (fig. 12a). Secondly, small displacement during moderate and small earthquakes occurred. These displacements were not large enough to force the eastward flowing channel segment to be abandoned, but were sufficiently large to produce river down cutting. Simultaneously these displacements make the fault scarp extended southward (fig. 12b). Thirdly, when a large magnitude earthquake occurred, it contributed slip to the fault scarp and resulted in southward extension of the western Zemuhe River channel. A new eastward flowing channel segment developed at the new southern end of the fault scarp; the old eastward flowing channel segment at the old southern end of the fault scarp was abandoned simultaneously (fig. 12c).

\section{Conclusions}

In this paper we describe and summarize earthquakes on the Zemuhe Fault recorded by abandoned ravines along an uplifted fault scarp, 
by paleoearthquake recorded in trenches and by examining historical records. Seven abandoned ravines on the Daqingliangzi fault scarp are interpreted to indicate seven events as large as the A.D. 1850 earthquake or A.D. 814 earthquake. The youngest four earthquakes were radiocarbon dated at A.D. 1850 , A.D. 814 , B.C. $4477 \pm 240$ or older, and between B.C. $4477 \pm 240$ and A.D. 814 , while the older three are only inferred. The seven events indicated by seven ravines should be all the large magnitude earthquakes in the Holocene. The trenches excavated by previous workers and by us reveal 2-4 earthquakes in the Holocene, most corresponding to those demonstrated by youngest five ravines on the Daqingliangzi uplift. We conclude that the average recurrence of large magnitude earthquake on the Zemuhe Fault in the Holocene is about 14001700 years, with a minimum of about 1000 years. In detail, however, recurrence intervals were variable with clusters in the Holocene. The first cluster occurred between B.C. 4250 and B.C. 6000 , and the second younger than A.D. 814. Each cluster lasted for about 1000-2000 years. Between the two clusters, there was a long tranquil period of about 5000 years, during which only one large magnitude earthquake (corresponding to ravine 5) occurred. Furthermore, using the maximum horizontal displacement of the A.D. 1850 earthquake and the $85 \pm 5 \mathrm{~m}$ cumulative lateral offset that accrued over the last 13-15 $\mathrm{ka}$, we inferred another average recurrence of 1000-1360 years, shorter than 1400-1700 years. This difference may arise because moderate and small earthquakes produced a quite high part of cumulative lateral displacement along the Zemuhe Fault during the Holocene.

\section{Acknowledgements}

We thank Mr. Song Fangmin, Ms. Zhang Wanxia and Dr. Li Chuanyou for their kind help in field investigation. We are grateful to Dr. Kenji Satake for his constructive criticism of the manuscript. Thanks are also due to Dr. A. Nicol for critical reviews that greatly improved this paper. Honglin He acknowledges the financial support partly by the SASAKAWA Scientific Grant from the Japan Science Society.

\section{REFERENCES}

Allen, C.R., Z. Luo, H. Qian, X. Wen, H. Zhou and W. HuANG (1991): Field study of a highly active fault zone: the Xianshuihe Fault of Southwestern China, Geol. Soc. Am. Bull., 103, 1178-1199.

CHen, S. (1993a): 1850 Earthquake of magnitude 7.5 between Xichang and Puge, in the appendix 'Representative earthquakes in Sichuan' of Active Faults and Earthquakes in Sichuan Province, edited by $\mathrm{R}$. TANG et al. (Seismological Press, Beijing, China), 20-28 (in Chinese).

CHEN, S. (1993b): 1536 Earthquake of magnitude 7.5 in Xinhua, in the appendix 'Representative Earthquakes in Sichuan' of Active Faults and Earthquakes in Sichuan Province, edited by R. TANG et al., (Seismological Press, Beijing, China), 4-7 (in Chinese)

Fen, Y., P. Du, Y. Jiang, S. Liu, Y. HuAng and T. Den (1995): Synthetical Report of Mapping and Investigation of the Zemuhe Fault (Working report of Sichuan Seismologocal Bureau, Chengdu, China), (in Chinese).

Gu, G. (1983): Earthquake Catalog of China (Scientific Press, Beijing, China), 8-266 (in Chinese).

He, H., F. Song and C. Li (1999): Topographic survey of micro-faulted landform and estimation of strike slip rate for the Zemuhe Fault, Sichuan Province, Seismol. Geol., 21 (4), 361-369 (in Chinese).

HuAnG, S. (1985): Preliminary study of the features of strong historic earthquakes and the assessment information of the general seismic trend, J. Seismol. Res., 8 (5), 485-495 (in Chinese).

HUANG, Z. (1979): Inquiry on the relationship between the tectonics of fault block and seismicity in Xichang, Sichuan, in Bulletin of Seismogeological Investigation in Strong Earthquake Area in Yunnan and Sichuan Provinces, edited by Southwest Intensity Investigatory Team, China Seismological Bureau (Seismological Press, Beijing, China), 104-120 (in Chinese).

LI, P. (Ed.) (1993): Xianshuihe-Xiaojiang Fault Zone (Seismological Press, Beijing, China), pp. 267 (in Chinese).

Lin, X. and X. GAN (1980): A study Ningnan-Xichang earthquake of 1850, J. Sichuan Univ., 1, 96-103 (in Chinese).

Molnar, P. and P. TAPPONNIER (1978): Active tectonics of Tibet, J. Geophys. Res., 83 (B11), 5361-5375.

REN, J. (1986): Seismotectonics of Xichang earthquake of 1850 and paleo-earthquake in Zemuhe Fault Zone, M.S. Thesis of Institute of Geology (China Seismological Bureau, Beijing, China), (in Chinese).

REN, J. and P. LI (1989): Earthquake-caused landforms and paleoseismic study on the northern segment of the Zemuhe Fault, Seismol. Geol., 11 (1), 27-34 (in Chinese).

REN, J. and P. LI (1993): The characteristics of surface faulting of 1850 earthquake in Xichang, Sichuan, Seismol. Geol., 15 (2), 97-106 (in Chinese).

SHEN, J., Y. WANG and F. Song (1997): The grouping of strikeslip data and seismicity of the Xiaojiang active fault, Earthquake Res. China, 13 (4), 366-375 (in Chinese).

SHEN, J., Y. WANG and F. Song (1998): Relative creep rate characteristic earthquake recurrence interval-example from the Xiaojiang Fault Zone in Yunnan, China, Seismol. Geol., 20 (4), 328-331 (in Chinese). 
Southwest InVESTIGATION TEAm OF EARTHQuAKE INTENSIty, China Seismological Bureau (Ed.) (1979): Bulletin of Seismogeological Investigation in Strong Earthquake Area in Yunnan and Sichuan Provinces (Seismological Press, Beijing, China), pp. 141 (in Chinese).

Wang, E., B.C. Burchfiel, L.H. Royden, L. Chen, J. Chen, W. Li and Z. CHEN (1998): Late Cenozoic XianshuiheXiaojiang, Red River, and Dali fault systems of Southwestern Sichuan and Central Yunnan, China, Geol. Soc. Am., Pap. 327, pp. 108
Wen, X., P. Du and D. LoNG (2000): New evidence of paleoearthquakes and date of the latest event on the Xiaoxiangling Mountain Segment of the Anninghe Fault Zone, Seismol. Geol., 22 (1), 1-8 (in Chinese).

WU, D. (1982): Identification of a paleoearthquake relic in Lijinbao Village, Xichang and its implication, Sichuan Seismol., 4, 22-24 (in Chinese).

XIE, Y. (1957): A new scale of seismic intensity adapted to the conditions in Chinese territories, Acta Geophys. Sin., 6 (1), 35-47 (in Chinese). 
